\title{
Article
}

\section{Relations between Intuitive Biological Thinking and Biological Misconceptions in Biology Majors and Nonmajors}

\author{
John D. Coley* and Kimberly Tanner ${ }^{\dagger}$ \\ ${ }^{*}$ Department of Psychology, Northeastern University, Boston, MA 02115-5000; ${ }^{\dagger}$ Department of Biology, San \\ Francisco State University, San Francisco, CA 94132
}

Submitted June 15, 2014; Revised October 8, 2014; Accepted October 8, 2014

Monitoring Editor: Hannah Sevian

\begin{abstract}
Research and theory development in cognitive psychology and science education research remain largely isolated. Biology education researchers have documented persistent scientifically inaccurate ideas, often termed misconceptions, among biology students across biological domains. In parallel, cognitive and developmental psychologists have described intuitive conceptual systems-teleological, essentialist, and anthropocentric thinking - that humans use to reason about biology. We hypothesize that seemingly unrelated biological misconceptions may have common origins in these intuitive ways of knowing, termed cognitive construals. We presented 137 undergraduate biology majors and nonmajors with six biological misconceptions. They indicated their agreement with each statement, and explained their rationale for their response. Results indicate frequent agreement with misconceptions, and frequent use of construal-based reasoning among both biology majors and nonmajors in their written explanations. Moreover, results also show associations between specific construals and the misconceptions hypothesized to arise from those construals. Strikingly, such associations were stronger among biology majors than nonmajors. These results demonstrate important linkages between intuitive ways of thinking and misconceptions in discipline-based reasoning, and raise questions about the origins, persistence, and generality of relations between intuitive reasoning and biological misconceptions.
\end{abstract}

\section{INTRODUCTION}

University biology education aims to produce emerging biology experts. However, strikingly little is known about the extent to which biology majors develop this expertise during their undergraduate years, and how this might occur. A host of studies in the emerging field of discipline-based biology education research have explored which biological ideas may be difficult for students to understand and, in the process, researchers have discovered a variety of ways in which

CBE Life Sci Educ March 2, 2015 14:ar8

DOI: $10.1187 /$ cbe.14-06-0094

Address correspondence to: John D. Coley (j.coley@neu.edu).

(c) 2015 J. D. Coley and K. Tanner. CBE-Life Sciences Education (C) 2015 The American Society for Cell Biology. This article is distributed by The American Society for Cell Biology under license from the author(s). It is available to the public under an Attribution-Noncommercial-Share Alike 3.0 Unported Creative Commons License (http://creativecommons.org/licenses/by-nc-sa/3.0).

"ASCB ${ }^{\circledR}$ " and" The American Society for Cell Biology ${ }^{\circledR}$ " are registered trademarks of The American Society for Cell Biology. biological novices think about biological ideas differently than biological experts do. These differences in conceiving the biological world-referred to in different disciplines as misconceptions, alternative conceptions, student perceptions, learner conceptions, misunderstandings, and by other descriptors-are important sources of insight into student thinking that can guide classroom teaching, student learning, curriculum development, assessment development, and further research. However, it is unclear whether these differences in biological thinking between novices and experts reflect unique difficulties with specific biological ideas or alternatively reflect the influence of more general cognitive processes on biological thinking. We propose that understanding the intuitive conceptual systems humans use more generally to reason about biology in informal contexts may be critical for understanding the process by which university students learn biological science in a formal educational setting. In the following sections, we explore what is known from developmental and cognitive psychology about informal biological reasoning. Additionally, we introduce three specific cognitive construals-informal, intuitive way of thinking about the world-that may have particular relevance for formal 
biology educators. Finally, we present hypotheses about potential interactions between these two seemingly unrelated arenas-intuitive ways of knowing from psychology and misconceptions observed in formal biology education.

\section{Intuitive Ways of Thinking and Cognitive Construals}

Three decades of cognitive science research have demonstrated that humans naturally, intuitively, and effortlessly reason about biological entities, structures, processes, and phenomena in predictable ways (e.g., Carey, 1985; Berlin, 1992; Inagaki and Hatano, 2002, 2006; Coley et al., 2002; Atran and Medin, 2008). We have dubbed these regularities cognitive construals (Coley and Tanner, 2012). A cognitive construal is an informal, intuitive way of thinking about the world. It might be a set of assumptions, a type of explanation, or a predisposition to a particular type of reasoning. Three such cognitive construals-teleological thinking, essentialist thinking, and anthropocentric thinking-are common themes spanning research on intuitive biological thought. We hypothesize that they may also have particular relevance to understanding challenges and misconceptions commonly encountered when students are learning life science concepts. Each is reviewed briefly in the following sections.

Teleological Thinking. Cognitive psychologists have shown that our minds are biased toward causal explanations (e.g., Gopnik, 2000; Sloman, 2005; Kahneman, 2012). We are quick to generate causal stories for events, from an uptick in the stock market to an above-average yield of tomatoes. Explaining an event by reference to the outcome or consequences of that event, rather than an antecedent of the event, is known as teleological thinking (Keil, 2006; Talanquer, 2007, 2013). In other words, teleological thinking is causal reasoning based on the assumption of a goal, purpose, or function. Kelemen (1999) argues that teleological thinking is a central component of adults' everyday thought. We make the teleological assumption that people's actions are directed toward certain goals and presume that human artifacts, such as chairs and coats, are designed by their creators to fulfill some intended purpose. As Kelemen emphasizes, teleological thinking provides an important component of adults' intuitive interpretations of why events occur or why objects have the properties they do.

Essentialist Thinking. Essentialist thinking is the tendency to believe that a core underlying property or feature of a biological structure, species, or system determines its overt features and identity. This cognitive construal is an assumption that people make about concepts. For cognitive scientists, concepts are mental representations of categories, along with related knowledge (Murphy, 2002). Essentialist thinking captures the idea that in addition to summarizing knowledge, concepts also involve a possibly implicit assumption that there is some unobservable essential property (an "underlying reality" or "true nature") common to members of a category that conveys identity and causes observable similarities among category members (Medin and Ortony, 1989; Ahn et al., 2001; Gelman, 2003).

One consequence of essentialist thinking is the belief that members of a category are relatively uniform with respect to shared properties - a shared essence should give rise to similar properties in all category members (e.g., Shtulman and Shulz, 2008), leading us to discard variability among category members as noise. An additional consequence of essentialist thinking is that superficial transformations (e.g., changes in appearance) should not affect category membership, which is ultimately based on the presence or lack of an essential property, rather than superficial features (Keil, 1989; Rips, 1989). A third is that category membership conveys innate potential; because of an underlying essence, category members not only share properties but also the propensity to develop certain characteristics over time (e.g., Gelman and Wellman, 1991; Solomon et al., 1996). In sum, essentialist thinking yields assumptions about uniformity and predictability of category members that reduce the complexity of incoming information to manageable levels.

Anthropocentric Thinking. Anthropocentric thinking involves distorting the place of human beings in the natural world. This can result in 1) the tendency to see humans as unique and biologically discontinuous with the rest of the animal world and 2) the tendency to reason about other organisms by analogy to humans. The first component involves the way in which human beings are incorporated into the intuitive taxonomy of living things. According to geneticists, humans are African great apes; we share a common ancestor who lived c. 5-8 million yr ago with our closest living relatives: chimpanzees. However, intuitive biological taxonomies-particularly those found in industrialized Western societies - tend to see humans as essentially separate and discontinuous from other species (e.g., Coley, 2007). The second component of anthropocentric thinking is the tendency to reason about unfamiliar biological species or processes by analogy to humans. Analogical reasoningtrying to understand an unfamiliar idea or situation by comparing it with something familiar-is a common strategy used across many domains of learning (Gentner and Smith, 2013). Intuitively, human beings are a familiar and accessible biological kind and are therefore a very tempting source of knowledge that is often misapplied to nonhuman living things. This can lead to both overattribution of human characteristics to similar organisms (e.g., Inagaki and Hatano, 1991) and underattribution of biological universals to dissimilar organisms (e.g., Carey, 1985).

Other Work on Intuitive Explanatory Frameworks. Our delineation of intuitive biological thought in terms of these foundational construals is very similar to the approach taken by Talanquer. Specifically, Talanquer has characterized in detail an intuitive explanatory framework in the domain of commonsense chemistry (Talanquer, 2006). This includes both "empirical assumptions" (including teleological and essentialist thinking, as applied to understanding chemical substances and processes) and "reasoning heuristics." Indeed, Talanquer has documented the presence of teleological thinking in particular in both common chemistry textbooks (Talanquer, 2007) and explanations about specific types of chemical reactivity (Talanquer, 2010, 2013). Likewise, Taber and Garcia-Franco (2010) have identified a number of spontaneous, intuitive ways of thinking about chemistry among English secondary students. We see this as a fruitful approach to understanding systematic misconceptions and 
take the inquiry a step further by documenting specific linkages between construals and misconceptions in the domain of biology.

In a similar vein, Evans and colleagues (2012) emphasize the importance of these cognitive construals as intuitive explanatory frameworks that contribute to the emergence of both understanding of and misconceptions about key concepts of evolution. Like Evans and colleagues, we acknowledge the importance of linking emergent scientific understanding with the development of intuitive conceptual frameworks. However, as detailed in the following sections, we see this linkage as relevant to a wider array of concepts across the life sciences.

\section{Misconceptions Observed in Formal Biology Education}

While psychology researchers have developed theoretical frameworks for understanding intuitive biological reasoning, science education researchers have independently documented a variety of scientifically inaccurate biological ideas held by biological novices. These misconceptions (also referred to as alternative conceptions, naïve conceptions, or preconceptions) are characterized as differing from a lack of knowledge in that they appear to be tenacious and retained in the presence of formal instruction unless explicitly addressed (Wandersee et al., 1994). Misconceptions appear to cut across boundaries such as age, ability, gender, and culture; moreover, instructors themselves have been shown to hold some of the same misconceptions as students (e.g., Arnaudin and Mintzes, 1985; Nehm and Schonfeld, 2007). Some misconceptions have been hypothesized to originate in or be exacerbated by formal education, such as biology instructors' use of the term "adapt" in teaching evolution, leading students to conceptualize individual organisms rather than populations, changing over time. However, biology educators at all levels tend to address misconceptions individually, without a more systematic approach to teaching and supporting students in grappling with these ideas. To the extent that misconceptions are seen as interrelated in the biology education literature, they are usually organized in terms of subject matter, and instructors tend to diagnose misconceptions using subject-based concept inventories, in areas such as evolution (e.g., Anderson et al., 2002), genetics (e.g., Smith et al., 2008), molecular biology (e.g., Shi et al., 2010), animal development (e.g., Knight and Wood, 2005), and microbiology (e.g., Marbach-Ad et al., 2009), to name a few. Some science education investigators have moved beyond analysis of individual misconceptions and have begun investigating patterns observed in students' explanations of scientific phenomena. Several scholars have explored the nature of students' explanations, connecting characteristics of students' explanations to models of causal reasoning and to models of scientific explanation drawn from philosophy of science writings (e.g., Grotzer, 2003; Braaten and Windschitl, 2011). Others have described patterns in students' intuitive reasoning, which includes misconceptions, and have organized these findings into learning progressions that characterize student reasoning related to carbon and water cycling (Mohan et al., 2009; Hartley et al., 2011; Gunckel et al., 2012).
The study of the nature and defining characteristics of misconceptions is an ongoing area of research. Some argue that misconceptions represent fragmentary, isolated "phenomenological primitives" (diSessa, 1988, 1993; Maskiewicz and Lineback, 2013). Others argue that misconceptions grow out of coherent intuitive conceptual frameworks used to understand, explain, and predict the world (e.g., Vosniadou, 1994, 2002; Taber and Garcia-Franco, 2010; Coley and Tanner, 2012). All agree that the presence of misconceptions does not indicate deficits but rather a mind actively engaged with the world trying to construct explanations for complex phenomena. As such, misconceptions should not be regarded as simply wrong ideas to be fixed but rather as common ways of thinking that can be important starting points for teaching and learning (e.g., Leonard et al., 2014). In fact, misconceptions are likely key in driving conceptual change in educational settings and engaging learners in recognizing their existing conceptions about how the world works, examining these ideas in the context of scientific evidence, and then changing and restructuring their conceptions toward more evidence-based, scientifically accurate ideas held by experts in a scientific field (Posner et al., 1982).

\section{Hypothesized Relations between Cognitive Construals and Biological Misconceptions}

Thus, cognitive science research has suggested that intuitive biological thought can be characterized by at least three distinct cognitive construals: teleological thinking, essentialist thinking, and anthropocentric thinking. Science education research has revealed a plethora of misconceptions that have generally been considered independent of one another. Unfortunately, scholarship in these disciplines remains largely isolated, and genuine disciplinary border crossing is rare. To address the dearth of interdisciplinary thinking, we have proposed a new theoretical framework that derives from considering the science education research literature in light of the cognitive psychology literature (Coley and Tanner, 2012). Specifically, we hypothesize that the hallmarks of intuitive biological thought most commonly studied in children by cognitive psychologists persist in the conceptual systems of undergraduate students. We hypothesize that what emerges when these students encounter university-level biological science are systematic clusters of biological misconceptions that transcend standard biological subjects like evolution and cellular respiration but share an underlying cognitive and conceptual basis. If this is so, seemingly disparate biological misconceptions across diverse subject areas may have common origins in underlying cognitive construals (see Table 1).

There is some empirical support for this framework; a small but important body of research within cognitive science has linked misconceptions about evolution to construal-based reasoning. For example, Evans (2008) has argued eloquently for the importance of intuitive construals in understanding the difficulties involved in learning and teaching evolutionary theory (see also Coley and Muratore, 2012; Gelman and Rhodes, 2012; Kelemen, 2012; Shtulman and Calabi, 2012). Shtulman and Schulz (2008) have shown that undergraduates who perceive animal categories as homogeneous-one aspect of essentialist thinking-have a less sophisticated and 
Table 1. Misconception challenge statements used in the present study, along with hypothesized related cognitive construal

\begin{tabular}{|c|c|c|}
\hline $\begin{array}{l}\text { Hypothesized related } \\
\text { cognitive construal }\end{array}$ & Biological misconception statement & References \\
\hline \multirow[t]{3}{*}{ Teleological thinking } & $\begin{array}{l}\text { Plants produce oxygen so that animals can } \\
\text { breathe. }\end{array}$ & $\begin{array}{l}\text { Wandersee, 1986; Stavy et al., 1987; Tamir, 1989; Anderson et al., 1990; } \\
\text { Leach et al., 1992; Songer and Mintzes, 1994; Kuech et al., 2003; } \\
\text { Özay and Ostas, 2003; Köse, } 2008\end{array}$ \\
\hline & $\begin{array}{l}\text { Species adapt to their environment in order to } \\
\text { survive. }\end{array}$ & $\begin{array}{l}\text { Bishop and Anderson 1990; Passmore and Stewart, 2002; Stern and } \\
\quad \text { Roseman, } 2004\end{array}$ \\
\hline & $\begin{array}{l}\text { Many species develop protective "camouflage" } \\
\text { to avoid predators. } \\
\text { Genes turn on so that a cell can develop properly. }\end{array}$ & $\begin{array}{l}\text { Bishop and Anderson 1990; Passmore and Stewart, 2002; Stern and } \\
\text { Roseman, } 2004\end{array}$ \\
\hline \multirow[t]{4}{*}{ Essentialist thinking } & $\begin{array}{l}\text { Homeostasis keeps the body static and } \\
\text { unchanging. }\end{array}$ & Westbrook and Marek, 1992 \\
\hline & $\begin{array}{l}\text { Apart from differences due to age and sex, } \\
\text { members of the same species are essentially } \\
\text { identical; any variability is biologically } \\
\text { unimportant. }\end{array}$ & $\begin{array}{l}\text { Greene, 1990; Anderson et al. 2002; Passmore and Stewart, 2002; } \\
\text { Shtulman, 2006; Gelman and Rhodes, } 2012\end{array}$ \\
\hline & $\begin{array}{l}\text { Different cells in an organism (e.g., skin, } \\
\text { muscle, nerve) contain different DNA. }\end{array}$ & Hackling and Treagust, 1984 \\
\hline & $\begin{array}{l}\text { Without outside influences, ecological commu- } \\
\text { nities will remain stable indefinitely. }\end{array}$ & D'Avanzo 2003 \\
\hline \multirow[t]{4}{*}{$\begin{array}{l}\text { Anthropocentric } \\
\text { thinking }\end{array}$} & $\begin{array}{l}\text { Humans have caused the majority of } \\
\text { extinctions. }\end{array}$ & AAAS, 2014b \\
\hline & Plants get their food from the soil. & $\begin{array}{l}\text { Stavy et al., 1987; Tamir, 1989; Anderson et al., 1990; Leach et al., 1992; } \\
\text { Songer and Mintzes, 1994; Wandersee, 1986; Kuech et al., 2003; } \\
\text { Özay and Ostas, 2003; Köse, } 2008\end{array}$ \\
\hline & $\begin{array}{l}\text { The heart decides how much blood is needed } \\
\text { throughout the body and adjusts the rate at } \\
\text { which it beats accordingly. }\end{array}$ & $\begin{array}{l}\text { Inagaki and Hatano, 2002; Morris et al., 2000; Miller and Bartsch, } \\
1997\end{array}$ \\
\hline & $\begin{array}{l}\text { Competition between organisms involves direct, } \\
\text { aggressive interaction. }\end{array}$ & AAAS, 2014a \\
\hline
\end{tabular}

accurate understanding of evolutionary principles than those who perceive animal categories to be variable. Similarly, Kelemen and Rossett (2009) have shown that higher levels of teleological thinking are associated with poorer performance on the Conceptual Inventory of Natural Selection (Anderson et al., 2002). In addition, Legare et al. (2013) have shown that anthropocentric narratives are less likely than scientifically accurate narratives to facilitate accurate evolutionary understanding in elementary school children. These studies show some linkages between cognitive construals and understanding of evolution but have not examined relations between cognitive construals and understanding biological science more generally.

On the other hand, biology education researchers have documented the existence of teleological and anthropocentric thinking among high school and university students (e.g., Tamir and Zohar, 1991; Friedler, et al., 1993; Zohar and Ginossar, 1998; Nehm and Ridgeway, 2011). Likewise, chemistry education researchers have systematically detailed intuitive frameworks for organizing knowledge about chemistry (e.g., Talanquer, 2006; Taber and Garcia-Franco, 2010) but have not systematically explored linkages between cognitive construals and systems of misconceptions. In the following sections, we propose to build on this foundation by investigating the relations between a wider range of biological misconceptions and the three cognitive construals that we hypothesize may give rise to these misconceptions.

Hypothesized Teleological Misconceptions. Teleological thinking is a widespread cognitive construal that is useful in helping us make sense of many aspects of the world around us. However, this natural form of explanation is often extended inappropriately in the domain of biology. Students at all levels commonly explain biological structures and processes by reference to their supposed purpose, goal, or function. The first section of Table 1 lists examples of misconceptions documented by multiple research groups. These span traditional subject areas in the life sciences, including plant respiration, evolution, and cellular development, but we hypothesize that they may all stem from teleological thinking. What these misconceptions share is a sense of forward-looking, goal-directed, outcome-driven causality that can obscure the underlying biological processes involved. Thus, we hypothesize that teleological thinking may underlie a variety of seemingly unrelated biological misconceptions and may thereby play a role in hindering students' transitions from novices to expert thinkers in biology.

Hypothesized Essentialist Misconceptions. Essentialist thinking, which includes the assumption that underlying essential properties cause external features, can lead to the inference that outward characteristics exhibited by members of any biologically relevant category-be it cells, species, or types of ecosystems-should be relatively uniform, static, and predictable. Consequences of essentialist thinking such as assumptions about homogeneity and stability have been widely discussed as impediments to both individual understanding of biological concepts (e.g., Shtulman and Schulz, 2008; Coley and Muratore, 2012; Gelman and Rhodes, 2012) and the progress of biological science as a discipline 
(e.g., Hull, 1965; Mayr, 1982). We hypothesize that essentialist thinking may strongly influence our intuitive understanding of biological entities and systems, as well as species. The second section of Table 1 lists examples of misconceptions documented by multiple research groups ranging from genetics to ecology. We hypothesize that essentialist thinking may underlie all of these misconceptions, including assumptions that simple one-to-one correspondence exists between essence (DNA) and observable properties, assumptions about species-wide homogeneity, and the view that ecological systems are static. Thus, like teleological thinking, essentialist thinking may provide an underlying explanation for a variety of seemingly unrelated biological misconceptions.

Hypothesized Anthropocentric Misconceptions. Anthropocentric thinking is a natural manifestation of our powerful analogical reasoning abilities. However, when applied to the life sciences, this can lead students to a distorted understanding of both humans and other species. The third section of Table 1 lists examples of diverse misconceptions that we hypothesize may all share an underlying origin in anthropocentric thinking. In these examples, anthropocentric thinking can lead to distortions of humans' role in the biological world, overattribution of human (or animal) functions to dissimilar organisms (e.g., plants), or personification of physiological processes. Similar to teleological and essentialist thinking, anthropocentric thinking may represent a third cognitive construal that underlies this set of seemingly unrelated biological misconceptions.

\section{Testing Hypotheses about Relations between Cognitive Construals and Biological Misconceptions}

As detailed above, we hypothesize that many common biological misconceptions may stem not from the complexity or opacity of the concepts themselves, but because they may arise from informal, intuitive, and deeply held ways of understanding the world (Coley and Tanner, 2012). Little is known about the presence and, more importantly, the relations between intuitive biological reasoning and discipline-based biological reasoning among young adults beginning their university studies. To address this gap in our collective knowledge, we investigated the following research questions among entering biology majors and entering students in majors outside the life sciences (henceforth, "nonmajors").

What Is the Prevalence of Hypothesized Construal-Based Misconceptions among Undergraduate Students, and How Do Biology Majors and Nonmajors Differ? We hypothesize that biological novices (both majors and nonmajors), will show clear evidence of the specific biological misconceptions described earlier (see Table 2). Incoming biology majors may show a somewhat lower prevalence of misconceptions due to more biology and related course work in high school or more previous interest-driven exploration of the topic.

What Is the Prevalence of Construal-Based Reasoning among Undergraduate Students, and How Does This Differ between Biology Majors and Nonmajors? We hypothesize that, because cognitive construals are an integral component of intuitive biological reasoning, both groups of biological novices (entering biology majors and nonmajors alike) will show clear evidence of cognitive construals in their explanations of biological ideas. Incoming biology majors may show a somewhat lower prevalence of construals in this context, in particular if their experiences in formal secondary education resulted in decreased application of intuitive construals to discipline-based problems.

How Are Construal-Based Reasoning and Biological Misconceptions Related, and Are Those Relations the Same for Biology Majors and Nonmajors? To the extent that intuitive cognitive construals underlie biological misconceptions, we hypothesize that the presence of construals will be positively associated with the strength and prevalence of hypothesized construal-based misconceptions. Moreover, we expect associations to be exclusive, such that, for example, teleological construals should be associated with hypothesized teleological misconceptions but not necessarily with hypothesized essentialist or hypothesized anthropocentric misconceptions. Finally, we hypothesize that these relations will hold equally for both biological novices who are entering biology majors and who are entering nonmajors, unless prior formal biology education has somehow mitigated these connections.

We present here an integrated research study that brings together the theoretical frameworks, research methodologies, and analytical approaches of both cognitive psychology and science education to test these hypotheses.

\section{METHOD}

\section{Participants}

A total of 137 undergraduate students at Northeastern University participated in the study. One group, which we will refer to as "biology majors" $(n=69)$ were first-year students enrolled in two sections of a seminar designed for freshman biology, biochemistry, and behavioral neuroscience majors with Advanced Placement (AP) biology credit. These students had all taken AP biology courses in high school and achieved a score of 4 or 5 on the AP Biology exam. These students participated as part of their normal classroom activities. The "nonmajors" group $(n=68)$ was composed of students enrolled in an introductory psychology course who participated to partially fulfill a course research hours requirement. Nonmajors were prescreened to ensure that they met two criteria. The first was that they were not majoring in biology, biochemistry, or behavioral neuroscience (nonmajors represented a wide variety of majors, most of which were in the humanities and social sciences) and the second was that they had earned AP credit in some subject other than biology. This was to roughly equate general academic ability in the two groups.

\section{Biological Misconception Statements}

To assess the spontaneous use of teleological thinking, essentialist thinking, and anthropocentric thinking in reasoning about biological science, we constructed 12 misconception statements. Four of these were hypothesized to be associated with each of the three construals. (These misconception statements are listed in Table 1.) Misconception statements 
were chosen to represent the five core concepts articulated in the Vision and Change in Undergraduate Biology initiative (AAAS, 2011): 1) evolution (the diversity of life forms that have evolved over time through mutations, selection, and genetic change; 2) structure and function (the basic units of biological structures that define the functions of all living things); 3) information flow, exchange, and storage (the influence of genetics on the control of the growth and behavior of organisms); 4) pathways and transformations of energy and matter (the ways in which chemical transformation pathways and the laws of thermodynamics govern the growth and change of biological systems); and 5) systems (the ways in which living things are interconnected and interact with one another).

We also chose statements that we hypothesized to be closely linked to one of the three cognitive construals discussed in Coley and Tanner (2012): teleological, essentialist, or anthropocentric thinking. Specifically, teleological statements were chosen to represent misconceptions based on the idea that an outcome, purpose, or goal plays a causal role in a biological process. Essentialist statements involved misconceptions based on several related ideas: that shared underlying essence results in homogeneity, that bodily systems and ecological communities are static unless perturbed, and that surface/functional differences should imply the presence of underlying differences. Finally, anthropocentric statements reflected misconceptions based on false analogies to animals, overestimates of the impact of humans across geological time, and personified views of organ function and competition.

We split the misconception statements into two comparable assessment forms of six statements each (two statements corresponding to each construal) and presented two statements, with different hypothesized underlying construals, per page. Each participant responded to one assessment form only and post hoc analysis suggested no systematic differences between forms. For each statement, participants indicated whether they agreed with the statement on a scale ( $1=$ "strongly disagree," $2=$ "disagree," $3=$ "agree," $4=$ "strongly agree," $5=$ "don't know"); this portion of their assessment responses will be referred to throughout as their "agreement with the biological misconception." Participants were additionally asked to provide detailed written explanations of their responses; this portion of their assessment responses will be referred to throughout as their "written reasoning about the biological misconception."

\section{Data Collection Procedure}

Biology majors were assessed during a full class period at the beginning of the academic year. The assessment form was distributed, and students were told to take their time and answer carefully. Nonmajors were assessed individually or in small groups in a laboratory setting and were given the same instructions. Misconception statements were presented in the context of a larger assessment tool that also included several measures of intuitive biological thinking drawn from the cognitive science literature. Misconception statements were always presented first to avoid any influence of the intuitive biology thinking measures on responses to the misconception statements. Completion of the entire assessment typically took 45-60 min. Only analyses of the misconception statements are presented here.

\section{Scoring and Statistical Analyses}

Assessing Presence of Misconceptions through Analysis of Agreement. To address our first research question, "What is the prevalence of biological misconceptions among undergraduate students, and how do biology majors and nonmajors differ?," we examined students' agreement or disagreement with the misconceptions statements as indicated by their responses to the five-point scale. We scored this in two ways.

Categorical Agreement. First, we examined agreement as a binary categorical variable. To do so, we classified each student as either "agreeing" (i.e., giving a rating of 3 or 4) or "disagreeing" (giving a rating of 1 or 2 ) with each individual misconception statement and compared the number of biology majors and nonmajors who agreed with zero, one, or two misconception statements of each type (teleological, essentialist, anthropocentric) via 2 (major) $\times 3(0 / 1 / 2$ agreements with misconception statements) chi-square analyses. To look at differences between majors and nonmajors in agreement with individual misconception statements, we conducted 2 (major) $\times 2$ (agree/disagree) chi-square tests separately for each of the 12 statements.

Degree of Agreement along a Continuum. Second, we examined participants' level of agreement with each type of misconception statement as a continuous measure. To do so, we averaged the two agreement ratings for each type of statement (teleological, essentialist, anthropocentric), yielding three scores for each student for each statement type. Scores could range from one to four, with higher scores indicating stronger agreement with the statements, which in turn may suggest stronger misconceptions. To examine differences among different types of misconception statements and between majors and nonmajors, we conducted a 2 (major) $\times 3$ (type of statement) mixed analysis of variance (ANOVA). All pairwise comparisons reported as significant are based on Bonferroni-corrected $t$ tests with $p<0.050$.

Assessing Presence of Cognitive Construals through Analysis of Written Reasoning. To address our second research question, "What is the prevalence of construal-based reasoning in discipline-based biological reasoning, and how does this differ between biology majors and nonmajors?," we coded students' explanations for the presence of teleological, essentialist, and anthropocentric thinking. To do so, we transcribed each written explanation students provided for their position on each misconception statement. Six trained coders, blind to the participants' major and the type of misconception statement, coded each response independently for the presence or absence of each construal (teleological, essentialist, and anthropocentric thinking). Thus, different construals could be identified within a single response. Coding criteria are summarized in Table 2, along with examples of responses for which coding decisions were unanimous. Because each challenge statement has important individual characteristics, the precise way that we applied the generic coding categories varied slightly from item to item; details are available from the authors upon request.

For the purpose of analyses, a response was considered to embody a construal when a majority of independent coders (i.e., four or more out of six) indicated the presence of 
Table 2. Coding criteria for identifying cognitive construals in written explanations with examples from student responses

\begin{tabular}{|c|c|c|}
\hline Cognitive construal & Coding criteria/definition & Examples of student language \\
\hline Teleological thinking & $\begin{array}{l}\text { Response includes one or more explanations of biological } \\
\text { structures, processes, or phenomena by reference to their } \\
\text { supposed purpose, goal, function, or outcome. }\end{array}$ & $\begin{array}{l}\text { "Adaptations are made in order to promote reproduc- } \\
\text { tion and the continuation of that particular species." } \\
\text { (biology major) } \\
\text { "Plants produce oxygen for all kinds of life forms to } \\
\text { help fuel the reactions necessary for daily life." } \\
\text { (nonmajor) }\end{array}$ \\
\hline Essentialist thinking & $\begin{array}{l}\text { Response includes one or more explanations of biological } \\
\text { structures, processes, or phenomena consistent with the } \\
\text { idea that underlying shared properties cause external } \\
\text { features, and that the outward characteristics exhibited } \\
\text { by members of any biologically relevant category-be it } \\
\text { cells, species, or types of ecosystems-should be relatively } \\
\text { uniform, static, and predictable. } \\
\text { This includes indirect reference to a biological category or } \\
\text { group that implies uniformity with respect to a property } \\
\text { or behavior via generic language, e.g., "cats eat mice." }\end{array}$ & $\begin{array}{l}\text { "The coding for each type of cell is different so that each } \\
\text { cell has a unique function." (biology major) } \\
\text { "Nature has a delicate balance, so without any drastic } \\
\text { changes, ecological communities will mostly remain } \\
\text { stable." (nonmajor) }\end{array}$ \\
\hline $\begin{array}{l}\text { Anthropocentric } \\
\text { thinking }\end{array}$ & $\begin{array}{l}\text { Response explains biological structures, processes, or } \\
\text { phenomena by comparison with or analogy to humans or } \\
\text { by mentioning humans, their roles, or their interventions. } \\
\text { Response includes the inappropriate assignment of human } \\
\text { (or animate) characteristics to nonhuman (or inanimate) } \\
\text { entities. }\end{array}$ & $\begin{array}{l}\text { "The heart does not regulate itself but is instructed by } \\
\text { the brain. The brain recognizes either an increase } \\
\text { or decrease in the levels of oxygen + carbon dioxide } \\
\text { in the body + adjusts the heart rate accordingly." } \\
\text { (biology major) } \\
\text { "Much like the nutrients humans and animals receive, } \\
\text { plants get their nutrients from the soil. While not } \\
\text { everything they need is in the soil, many are." } \\
\text { (nonmajor) }\end{array}$ \\
\hline
\end{tabular}

that construal in that response. To assess the prevalence of each cognitive construal in students' biological reasoning, we compared the number of biology majors versus nonmajors who used each construal at least once across all six of their written explanations. We also conducted a 2 (major) $\times 3$ (construal) $\times 2$ (form) mixed ANOVA on the number of explanations (out of six) in which each construal was used by each student. We included "form" as a variable, because the two different forms of the assessment (each administered to roughly half of the participants) contained different misconception statements. We followed up this ANOVA with independent-samples $t$ tests and univariate ANOVAs run separately for biology majors and nonmajors, for which all pairwise comparisons reported as significant are based on Bonferroni-corrected $t$ tests with $p<0.050$.

Assessing Relations between Misconceptions and Cognitive Construals. We tested our third research question, "How are construal-based reasoning and misconceptions related, and are those relations the same for biology majors and nonmajors?," in two ways. First, in order to examine relations between individual misconceptions and the construals we hypothesized to be related to them, for each misconception statement, we classified each participant based on 1) whether they agree or disagreed with the statement (as an indication of whether they held the misconception) and 2) whether the construal we hypothesized to be associated with that misconception was present in their written explanation or not. We then conducted $2 \times 2$ chi-square analyses on these data separately for biology majors and nonmajors and combined for all students. Second, in order to examine more general relations between frequency of types of misconceptions and the construals we hypothesized to be associated with them, we ran multiple regression analyses. We used the frequency of each cognitive construal (teleological, essentialist, and anthropocentric thinking) across all written explanations as predictor variables and ran three different regressions, each of which used the average agreement with each specific type of misconception statement as an outcome variable. We performed these analyses for all students and also separately for biology majors and nonmajors.

\section{RESULTS}

We organize the results to address the three research questions raised previously. First, what is the prevalence of biological misconceptions among undergraduate students, and how do biology majors and nonmajors differ? Second, what is the prevalence of intuitive cognitive construals in discipline-based biological reasoning, and how does this differ between biology majors and nonmajors? Third, how are construal-based reasoning and misconceptions related, and are those relations the same for biology majors and nonmajors?

\section{Prevalence of Biological Misconceptions Among Biology Majors and Nonmajors}

Categorical Agreement. All together, 93\% of biology majors agreed with at least one misconception statement, as did $98 \%$ of nonmajors. Individual misconception statements varied widely in the degree to which students agreed with them, ranging from a high of $87 \%$ of students agreeing that "Species adapt to their environment in order to survive" to a low of $14 \%$ of students agreeing that "Different cells in an organism (e.g., skin, muscle, nerve) contain different DNA." Recall that each student responded to two misconception statements of each type (teleological, essentialist, anthropocentric). The percentage of biology majors and 


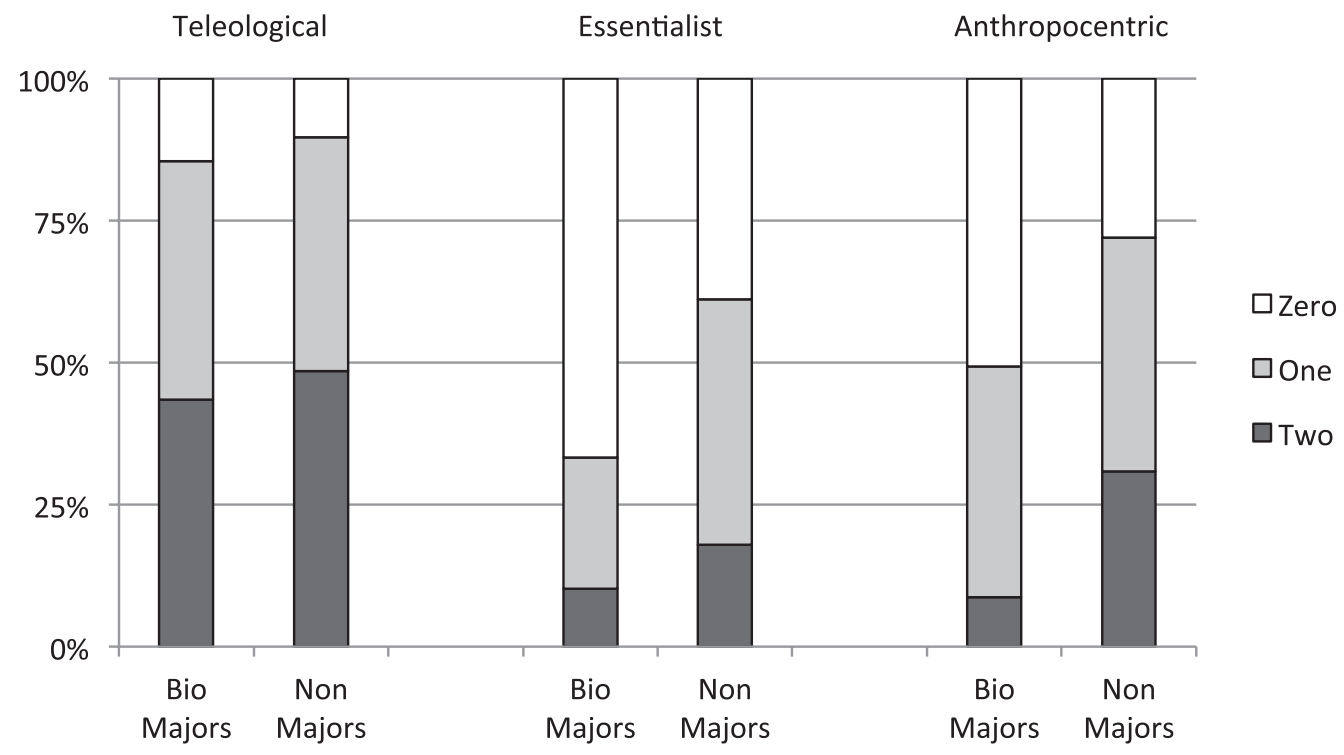

Figure 1. Percentage of students agreeing with zero, one, or two teleological, essentialist, or anthropocentric misconception statements.

nonmajors who agreed with zero, one, or two statements of each type is depicted in Figure 1. Students rarely selected the "don't know" option on the agreement scale $(M=0.28$ times out of six opportunities). Not surprisingly, such responses were more frequent for nonmajors $(M=0.43)$ than for biology majors $(M=0.14, t(135)=2.79, p=0.006)$. These responses were excluded from further analyses and represent $<5 \%$ of all responses. In the sections following, we examine agreement separately for each type of misconception statement.

Teleological Misconceptions. As depicted in Figure 1, the number of students agreeing with zero, one, or two statements did not vary by major for teleological misconceptions $\left(\chi^{2}(2,137)=0.68, p=0.711\right)$. As seen in Figure 2, three of the four teleological misconception statements were endorsed by more than $50 \%$ of students. Indeed, more than $75 \%$ of students from both groups agreed with teleological statements having to do with evolution ("Species adapt to their environment in order to survive" and "Many species devel- op protective camouflage' to avoid predators"). Majors and nonmajors did not differ on these statements but did so on the remaining two. Specifically, more nonmajors than majors agreed that "Plants produce oxygen so that animals can breathe" $\left(\chi^{2}(1,67)=8.80, p=0.003\right)$, whereas more biology majors than nonmajors agreed that "Genes turn on so that a cell can develop properly" $\left(\chi^{2}(1,58)=6.28, p=0.012\right)$.

Essentialist Misconceptions. In Figure 1, we see evidence that nonmajors were more likely to agree with essentialist misconception statements than biology majors. Specifically, nonmajors were more likely than majors to agree with one misconception statement (43 vs. 23\%), whereas biology majors were more likely than nonmajors to agree with none of the misconception statements (67 vs. $39 \%$, $\left.\chi^{2}(2,136)=10.60, p=0.005\right)$. Agreement with individual statements is depicted in Figure 3, which shows that the only essentialist misconception statement garnering more than 50\% agreement was "Without outside influences, ecological communities will remain stable indefinitely."

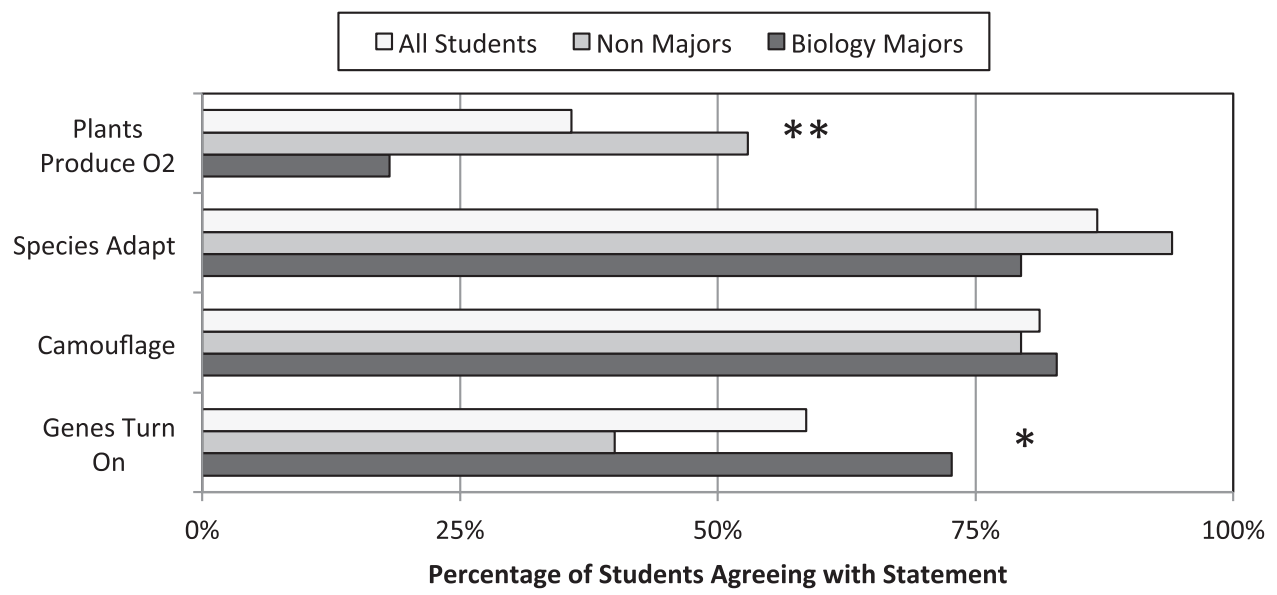

Figure 2. Percentage of students agreeing with each teleological misconception statement. Note: biology majors and nonmajors differ via chi-square test: ${ }^{*}, p<0.05 ;{ }^{* *}, p<0.01$. 


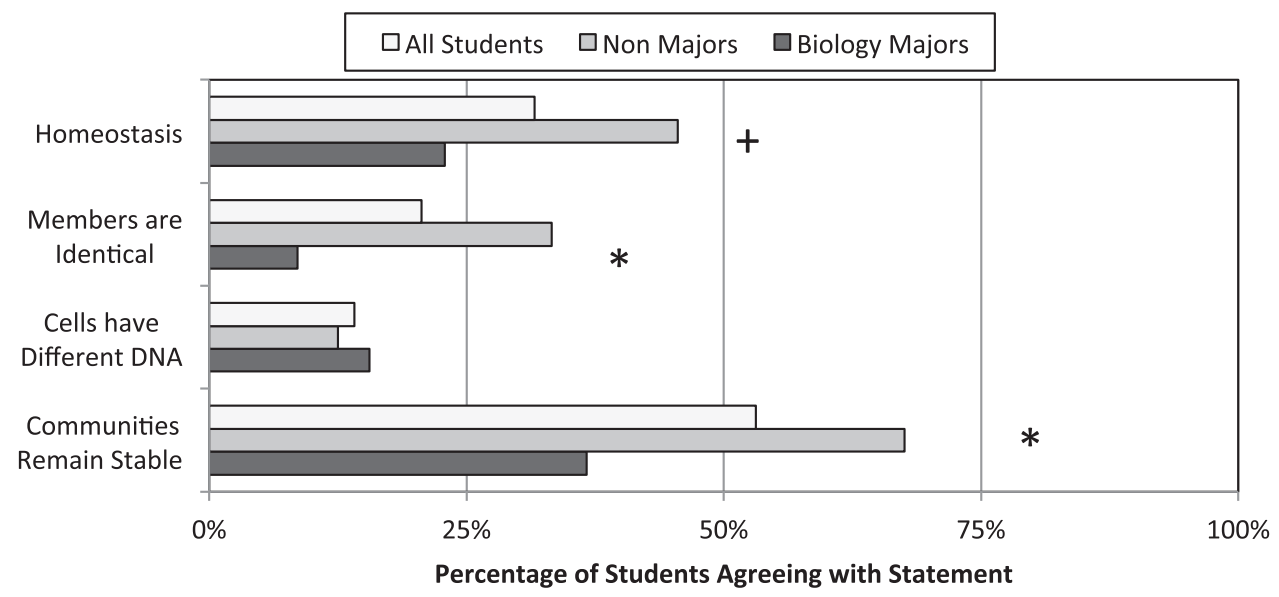

Figure 3. Percentage of students agreeing with essentialist misconception statements. Note: biology majors and nonmajors differ via chisquare test:,$+ p<0.10 ; *, p<0.05$.

Agreement with other essentialist statements was relatively low; however, consistent differences between biology majors and nonmajors emerged. More nonmajors than majors agreed with the "ecological communities" statement $\left(\chi^{2}(1,64)=6.14, p=0.013\right)$, and more nonmajors also agreed that "members of the same species are essentially identical; any variability is biologically unimportant" $\left(\chi^{2}(1,68)=6.37\right.$, $p=0.012$ ). Marginally more nonmajors than majors agreed that "homeostasis keeps the body static and unchanging" $\left(\chi^{2}(1,57)=3.19, p=0.074\right)$.

Anthropocentric Misconceptions. Nonmajors were also more likely than biology majors to agree with anthropocentric misconception statements (see Figure 1). Specifically, nonmajors were more likely than majors to agree with both statements (31 vs. $9 \%$ ), whereas biology majors were again more likely than nonmajors to agree with none of the misconception statements (51 vs. $\left.28 \%, \chi^{2}(2,136)=13.07, p=0.001\right)$. Response patterns for individual statements are depicted in Figure 4, which shows that a majority of students (including $49 \%$ of biology majors) agreed that "Plants get their food from the soil." Although nonmajors agreed more than biology majors with each anthropocentric statement, this difference was only statistical- ly reliable for "Competition between organisms involves direct, aggressive interaction" $\left(\chi^{2}(1,67)=6.67, p=0.010\right)$.

Degree of Agreement along a Continuum. As depicted in Figure 5, ANOVA showed that average agreement ratings were highest for teleological statements, intermediate for anthropocentric statements, and lowest for essentialist statements, $F(2,268)=69.26, p<0.001$, post hoc pairwise $p<0.05$. Moreover, mean agreement was higher among nonmajors $(M=2.60)$ than among biology majors $(M=2.21, F(1,134)=$ $23.63, p<0.001)$; this was true for all three types of misconception statements. The interaction was not significant.

\section{Prevalence of Cognitive Construals in Written Explanations of Biology Majors and Nonmajors}

Cognitive construals were used by a majority of students in their written explanations for their positions on the misconception statements; the percentage of students who used each construal at least once in their written responses to the six misconception statements is depicted in Figure 6. Altogether, $58 \%$ of students used teleological reasoning at least once, $88 \%$ used essentialist reasoning at least once, and

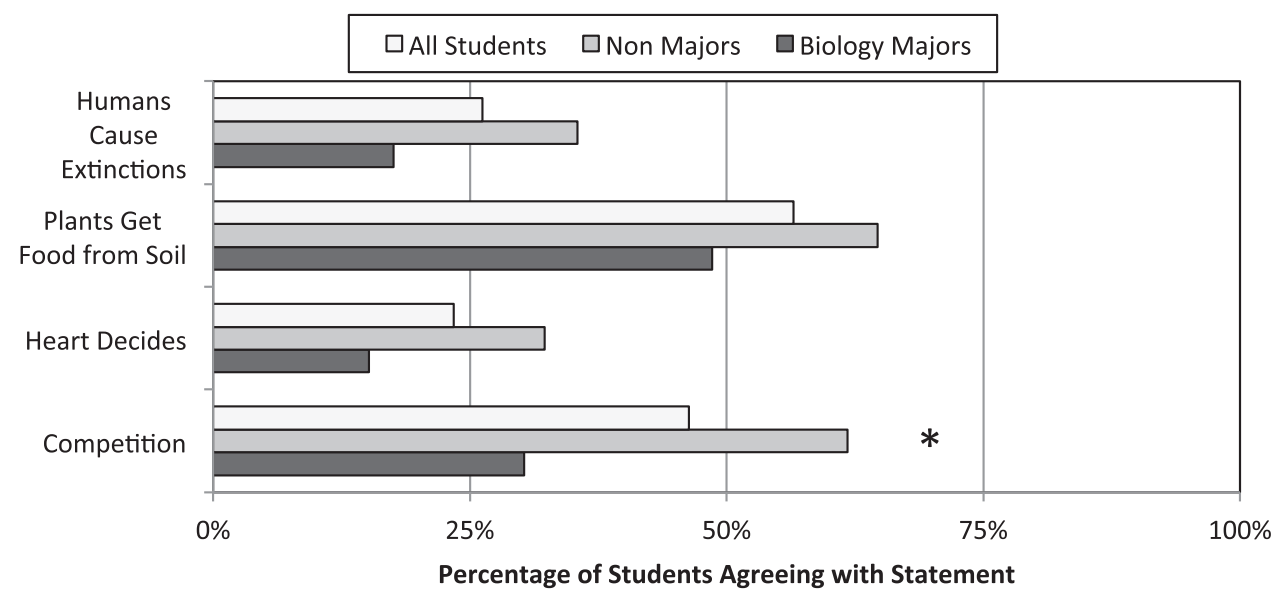

Figure 4. Percentage of students agreeing with anthropocentric misconception statements. Note: biology majors and nonmajors differ via chi-square test: ${ }^{*}, p<0.05$. 


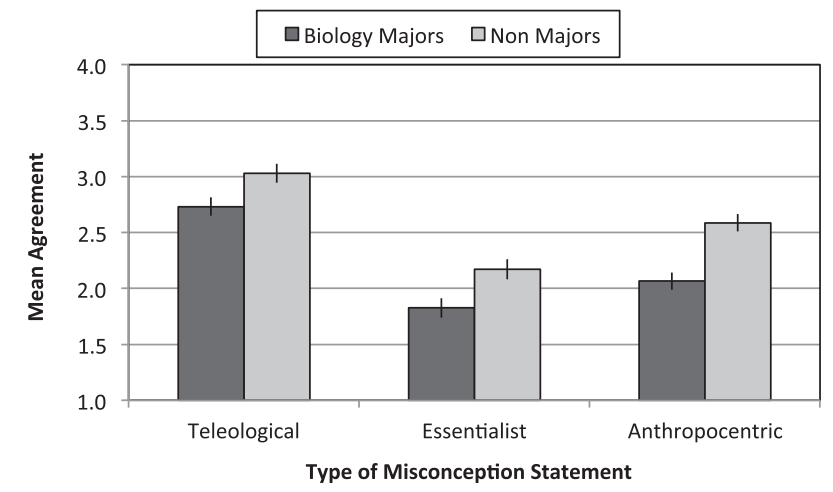

Figure 5. Mean agreement with each type of misconception statement for biology majors and nonmajors (error bars represent \pm 1 SEM).

$68 \%$ used anthropocentric reasoning at least once. Biology majors and nonmajors did not differ in the frequency with which they used any construal at least once in their written explanations $\left(\chi^{2}(1,136)<1.00, p>0.420\right)$.

When we analyzed the mean number of times each student used each type of construal, ANOVA revealed that essentialist construals were more common than anthropocentric construals, which in turn were more common than teleological construals $(F(2,270)=3.63, p=0.028)$. However, this pattern differed for biology majors versus nonmajors, as indicated by a significant interaction between construal and major $(F(2,264)=3.72, p=0.025)$. As can be seen in Figure 7, for biology majors, essentialist construals were more common than teleological or anthropocentric construals. In contrast, for nonmajors, essentialist and anthropocentric construals were more common than teleological construals. Anthropocentric construals were more common for nonmajors than for biology majors $(t(135)=2.12, p=$ 0.036), but differences for other construals were not statistically reliable.

There were no differences in evidence for cognitive construal-based reasoning in the written responses to the two forms of the assessment.

Teleological

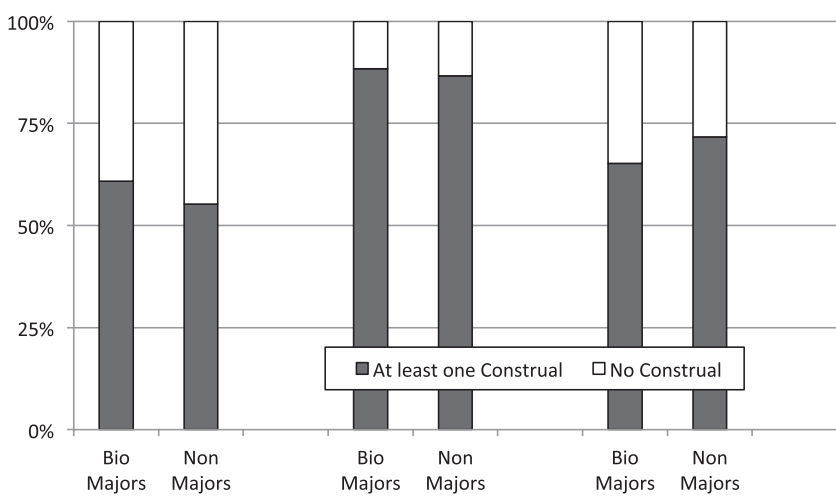

Figure 6. Percentage of students using at least one teleological, essentialist, or anthropocentric construal in their written explanations.

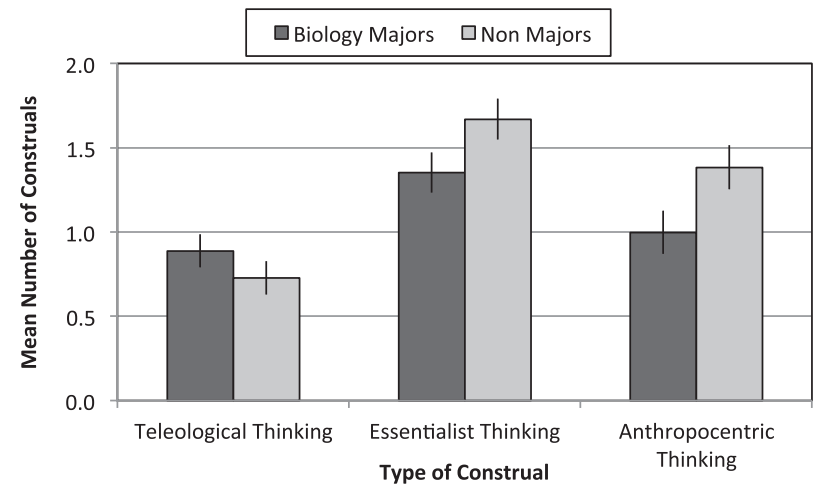

Figure 7. Mean number of teleological, essentialist, and anthropocentric construals in written explanations among biology majors and nonmajors (error bars represent \pm 1 SEM).

\section{Relations Between Biological Misconceptions and Cognitive Construals}

Relations between Individual Misconceptions and Construals. If agreement with a particular misconception stems from a specific underlying cognitive construal, then students who hold that misconception should be more likely to use that construal in their written explanations than students who do not hold that misconception. For eight of the 12 misconception statements we examined, this prediction was supported. Results of the chi-square analyses for these individual statements are presented in Table 3.

Hypothesized Teleological Misconceptions. When responses to individual misconception statements were considered, agreement was associated with teleological reasoning for three of the four hypothesized teleological misconceptions (see Table 3). As can be seen in Figure 8, for these three items, students who agreed with the misconception statement were more likely to explain their position in a way that demonstrated teleological reasoning than students who disagreed with the statement. Results for the fourth item- "genes turn on"-although not statistically significant, still trended in the same direction.

Hypothesized Essentialist Misconceptions. Agreement with all four individual hypothesized essentialist misconception statements was associated with essentialist reasoning (see Table 3). As can be seen in Figure 9, students who agreed with the misconception statement were more likely to explain their position in a way that demonstrated essentialist reasoning than students who disagreed with the statement.

Hypothesized Anthropocentric Misconceptions. Agreement and anthropocentric reasoning were only associated for one hypothesized anthropocentric item, "humans cause extinctions" (see Table 3). Nevertheless, as can be seen in Figure 10, for this item, as well as the "plants get food" item $(p=0.149)$, students who agreed with the misconception statement were more likely to explain their position in a way that demonstrated anthropocentric reasoning than students who disagreed with the statement.

Relations between Types of Misconceptions and Construals. If the extent to which students hold a type of misconception 
Table 3. Results of chi-square analyses for item-wise agreement-by-construal comparisons for biology majors, nonmajors, and all students combined.

\begin{tabular}{|c|c|c|c|c|}
\hline Hypothesized underlying construal & Misconception & All students & Biology majors & Nonmajors \\
\hline Teleological thinking & $\begin{array}{l}\text { Camouflage } \\
\text { Species adapt } \\
\text { Plants produce } \mathrm{O}_{2} \\
\text { Genes turn on }\end{array}$ & $\begin{array}{l}* * * \\
* \\
* \\
-\end{array}$ & $\begin{array}{l}* \\
* \\
- \\
-\end{array}$ & $\begin{array}{l}* * \\
- \\
- \\
-\end{array}$ \\
\hline Essentialist thinking & $\begin{array}{l}\text { Homeostasis } \\
\text { Communities remain stable } \\
\text { Cells have different DNA } \\
\text { Members are identical }\end{array}$ & $\begin{array}{l}* \\
* * * \\
* * * \\
* * *\end{array}$ & $\begin{array}{l}- \\
* \\
* * \\
*\end{array}$ & $\begin{array}{l}+ \\
* \\
* * \\
* * *\end{array}$ \\
\hline Anthropocentric thinking & $\begin{array}{l}\text { Humans cause extinction } \\
\text { Plants get food } \\
\text { Heart decides } \\
\text { Competition }\end{array}$ & $\begin{array}{l}* * \\
- \\
- \\
-\end{array}$ & $\begin{array}{l}* \\
- \\
- \\
-\end{array}$ & $\begin{array}{l}* * \\
+ \\
- \\
-\end{array}$ \\
\hline $\begin{array}{l}-p>0.10 \\
{ }^{+} p<0.10 \\
{ }^{*} p<0.05 \\
{ }^{* *} p<0.01 \\
{ }^{* *} p<0.001\end{array}$ & & & & \\
\hline
\end{tabular}

\section{Camouflage}

$\square$ Construal Present $\square$ Construal Absent

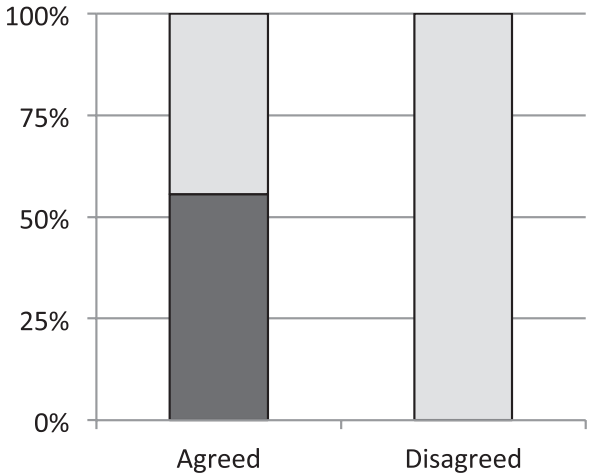

Plants Produce 02

$\square$ Construal Present $\quad \square$ Construal Absent

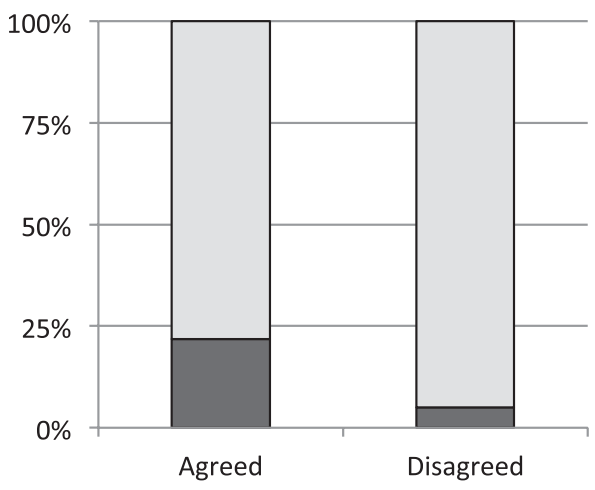

Species Adapt

$\square$ Construal Present $\square$ Construal Absent

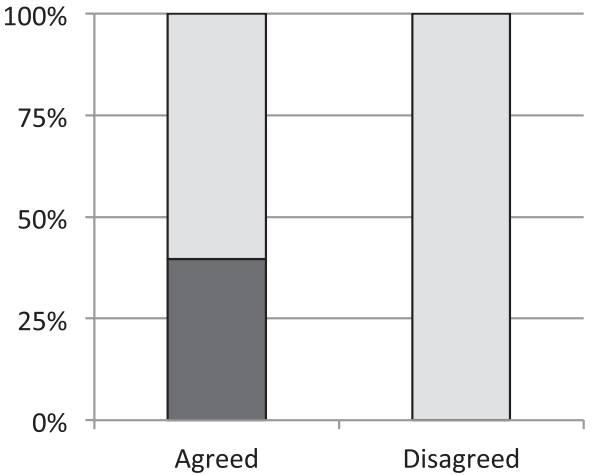

Genes Turn On

$\square$ Construal Present $\quad \square$ Construal Absent

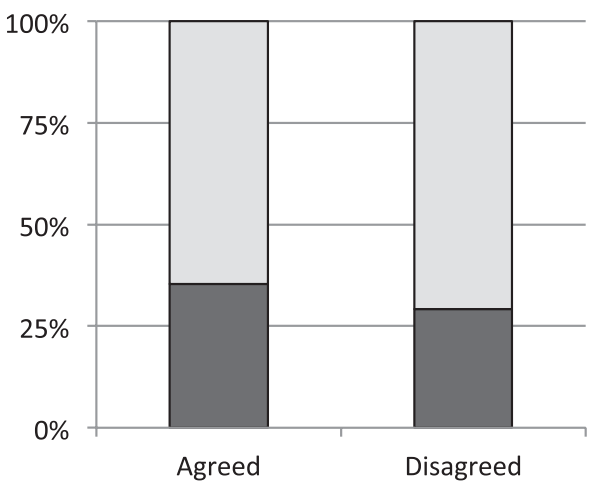

Figure 8. Percentage of students who showed evidence of teleological construals in their written explanations as a function of whether they agreed or disagreed with the misconception statement. 


\section{Homeostasis}

$\square$ Construal Present $\square$ Construal Absent

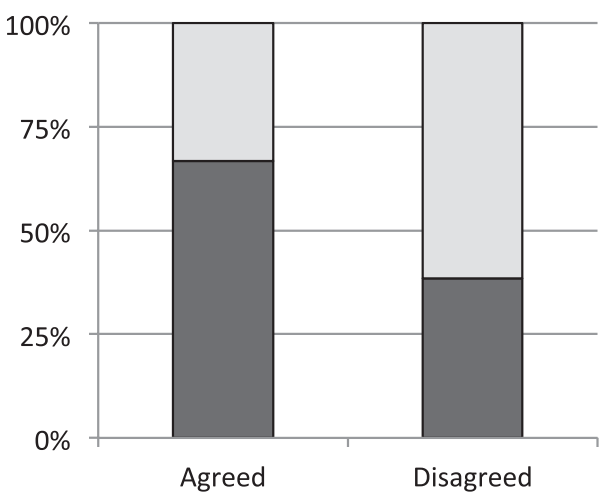

Cells have Different DNA

$\square$ Construal Present $\square$ Construal Absent

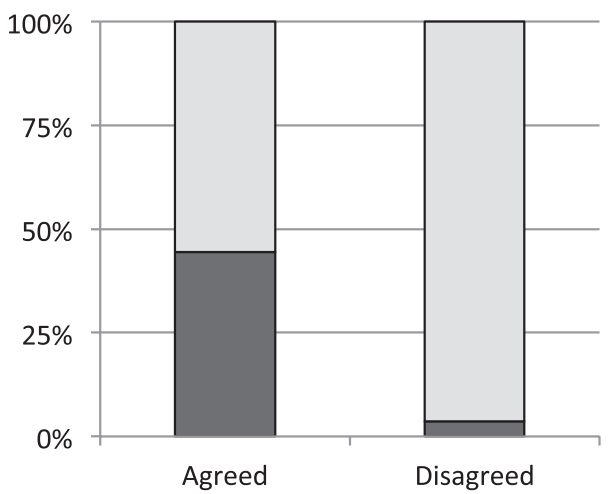

\section{Communities Remain Stable}

$\square$ Construal Present $\quad \square$ Construal Absent

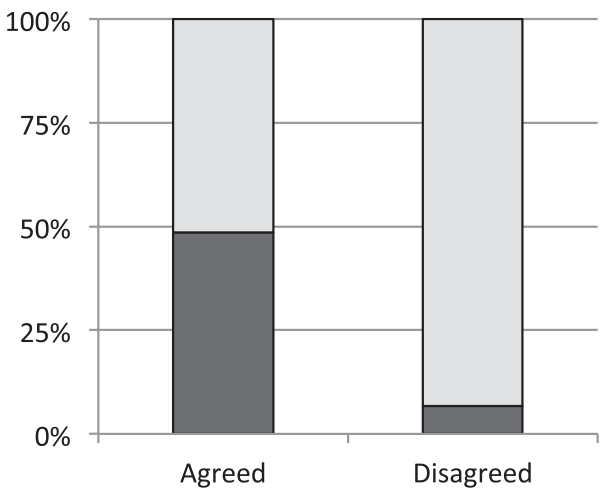

Members are Identical

$\square$ Construal Present $\square$ Construal Absent

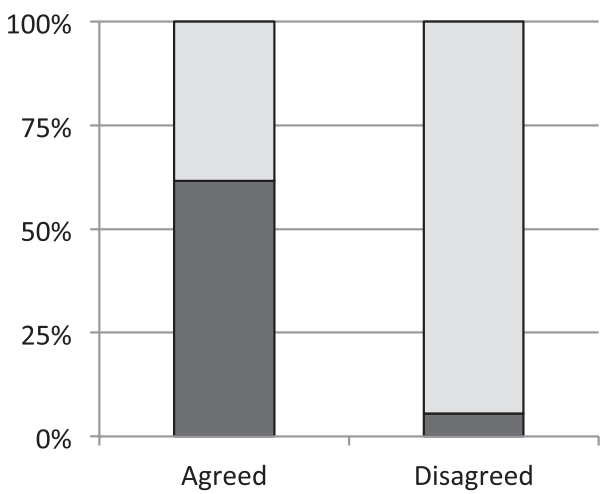

Figure 9. Percentage of students who showed evidence of essentialist construal in their written explanations as a function of whether they agreed or disagreed with the misconception statement.

stems from their tendency to use a specific cognitive construal, then the extent to which students agree with that type of misconception should be associated with the frequency of their use of that cognitive construal and not necessarily associated with the frequency of their use of other construals. For two of the three types of misconceptions we examined, this prediction was supported.

Based on regression analyses, students who agreed more with hypothesized teleological misconception statements also demonstrated more teleological thinking in their written explanations to all misconception statements; importantly, agreement with hypothesized teleological misconceptions was unrelated to frequency of essentialist or anthropocentric thinking. When considered separately, this pattern held for biology majors but not for nonmajors (see Table 4). Likewise, students who agreed more with hypothesized essentialist misconception statements also showed more essentialist thinking in their written explanations to all misconception statements but were no more likely to show evidence of teleological or anthropocentric thinking. Again, when considered separately, this pattern held for biology majors but not for nonmajors (see
Table 4). In contrast, regression analyses revealed no relation between agreement with hypothesized anthropocentric misconception statements and frequency of any type of cognitive construal, for biology majors or nonmajors (see Table 4).

\section{DISCUSSION}

Research and theory development in cognitive psychology and science education research remain largely isolated. Biology education researchers have documented persistent scientifically inaccurate ideas, often termed misconceptions, among biology students in multiple biological domains. In parallel, cognitive and developmental psychologists have described intuitive conceptual systems-teleological, essentialist, and anthropocentric thinking-that humans use to reason about biology. We have hypothesized that seemingly unrelated biological misconceptions may have common origins in these intuitive ways of knowing, termed cognitive construals (Coley and Tanner, 2012). In this paper, we investigated the following questions: 1) What is the prevalence 


\section{Humans Cause Extinctions}

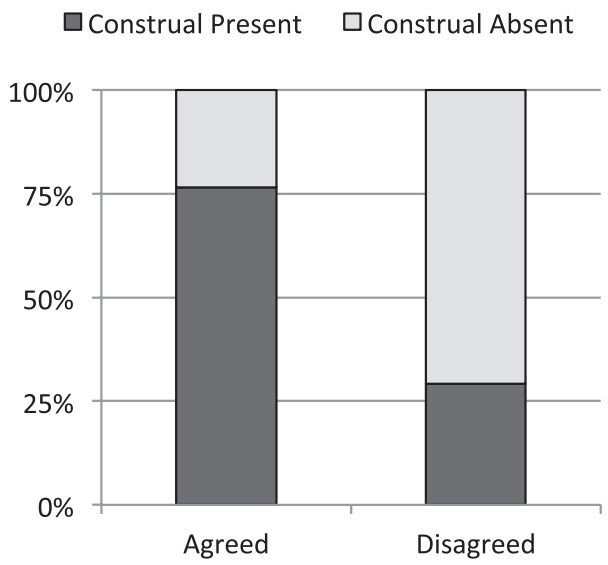

Heart Decides

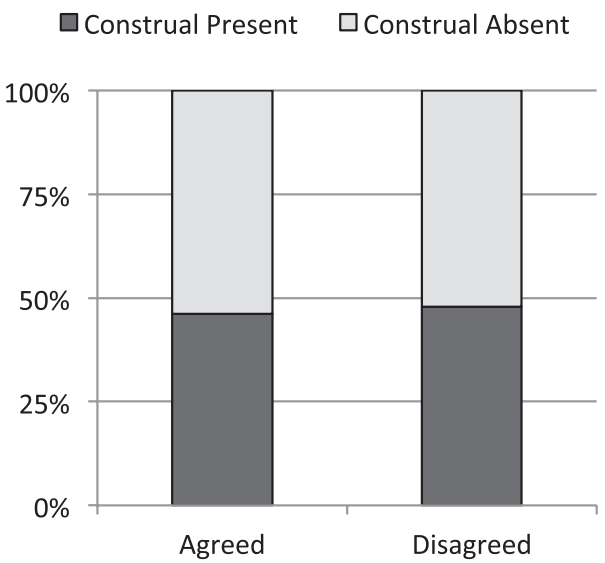

\section{Plants Get Food from the Soil}

$\square$ Construal Present $\quad \square$ Construal Absent

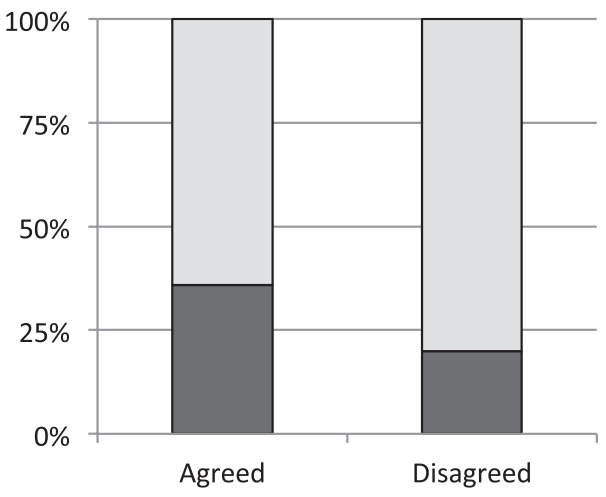

Competition

$\square$ Construal Present $\quad \square$ Construal Absent

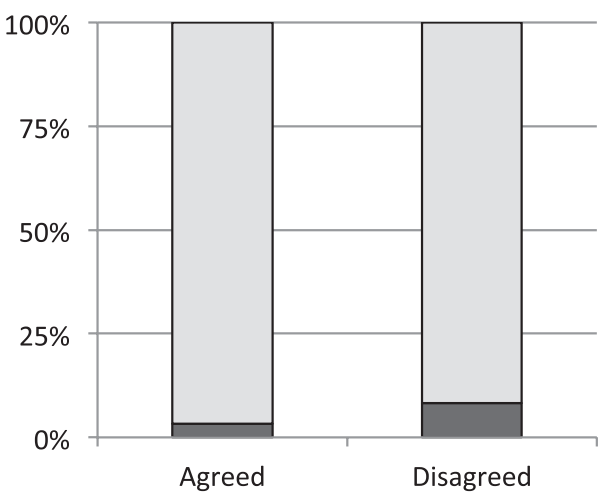

Figure 10. Percentage of students who showed evidence of anthropocentric construals in their written explanations as a function of whether they agreed or disagreed with the misconception statement.

of construal-based misconceptions among undergraduate students, and how do biology majors and nonmajors differ? 2) What is the prevalence of construal-based reasoning in discipline-based biological reasoning, and how does this differ between biology majors and nonmajors? 3) How are construal-based reasoning and misconceptions related, and are those relations the same for biology majors and nonmajors? In the following sections, we explore the implications of our results for each of these research questions in the contexts of formal university biology education, biology education research, and cognitive and developmental psychology, as well as potential future research directions.

\section{What Is the Prevalence of Biological Misconceptions among Undergraduate Students, and How do Biology Majors and Nonmajors Differ?}

While many assessment tools have been developed at the college level to diagnose biological misconceptions, there has been less systematic investigation of the nature and origins of those misconceptions that persist among science majors in higher education. To assess the presence of biological misconceptions, we simply asked participants whether they agreed or disagreed with a series of biological misconception statements. Our results suggest that the vast majority of undergraduates-biology majors (93\%) and nonmajors (98\%) alike-agreed with at least one biological misconception. Overall, nonmajors were more likely to agree with misconception statements than biology majors, and this difference was most pronounced for misconceptions hypothesized to correspond to essentialist and anthropocentric thinking. However, what is perhaps most striking is the similarity between majors and nonmajors. For six of 12 misconception statements, the two groups did not differ statistically on the likelihood of agreeing with the statement. And although agreement ratings were higher on average for nonmajors than for majors, both groups showed the same relative ordering-agreeing most with teleological misconceptions, followed by anthropocentric and finally essentialist misconceptions. 
Table 4. Relations between agreement with biological misconception statements and presence of cognitive construals in written explanations

\begin{tabular}{|c|c|c|c|c|}
\hline \multirow{2}{*}{$\begin{array}{l}\text { Agreement with misconception } \\
\text { statements }\end{array}$} & \multicolumn{3}{|c|}{ Frequency of cognitive construals in written explanations ${ }^{a}$} & \multirow[b]{2}{*}{$r^{2}$} \\
\hline & Teleological thinking & Essentialist thinking & Anthropocentric thinking & \\
\hline \multicolumn{5}{|l|}{ All students: Agreement with... } \\
\hline Teleological misconceptions & $0.224^{* *}$ & 0.086 & 0.127 & $0.087^{* *}$ \\
\hline Essentialist misconceptions & -0.027 & $0.283^{* * *}$ & -0.034 & $0.080^{*}$ \\
\hline Anthropocentric misconceptions & 0.057 & 0.190 & -0.007 & 0.032 \\
\hline \multicolumn{5}{|l|}{ Biology majors: Agreement with... } \\
\hline Teleological misconceptions & $0.309^{*}$ & 0.123 & 0.036 & $0.141^{*}$ \\
\hline Essentialist misconceptions & 0.190 & $0.319 * *$ & -0.189 & $0.168^{* *}$ \\
\hline Anthropocentric misconceptions & 0.119 & 0.195 & -0.112 & 0.063 \\
\hline \multicolumn{5}{|l|}{ Nonmajors: Agreement with... } \\
\hline Teleological misconceptions & 0.141 & 0.032 & 0.141 & 0.044 \\
\hline Essentialist misconceptions & -0.174 & 0.176 & -0.039 & 0.060 \\
\hline Anthropocentric misconceptions & 0.091 & 0.061 & 0.036 & 0.014 \\
\hline
\end{tabular}

For ease of interpretation, any entries in the table for which $p \leq 0.05$ appear in bold.

${ }^{*} p \leq 0.05$.

$* p \leq 0.01$.

$* * * p \leq 0.001$.

${ }^{\mathrm{a}}$ Entries represent standardized regression coefficients $(\beta)$.

Because the biological misconceptions used here represent only a small subset of possible misconceptions in these subject areas, differences among types of statements should be interpreted with caution. Although we chose the misconception statements to correspond to different underlying cognitive construals, we made only informal attempts to equalize the a priori plausibility of the statements, and we did not draw the statements randomly from a larger sample of potential misconceptions. Therefore, we cannot claim that, for example, misconceptions based on teleological thinking are stronger in general than misconceptions based on essentialist thinking; this may be an artifact of the misconceptions we examined.

Although the proliferation of concept inventories and the current dialogue about the nature of misconceptions suggest that instructors in higher life sciences education are attending to misconceptions, these results demonstrate the importance of further research on the nature and origins of misconceptions and their roots in intuitive student reasoning. The small but consistent difference in misconceptions between incoming biology majors and nonmajors suggests that advanced high school course work in biology and/or an underlying interest in and facility with the life sciences have some effect on biological misconceptions. Nevertheless, our data document persistent biological misconceptions among both majors and nonmajors. This contradicts a tacit assumption that emerging experts, namely university-level biology majors, do not hold the same misconceptions that have been previously documented among younger students, K-12 teachers, nonmajors, and the general public.

\section{What Is the Prevalence of Construal-Based Reasoning among Undergraduate Students, and How Does This Differ between Biology Majors and Nonmajors?}

While extensive research on construal-based reasoning has been conducted in young children, investigation of the "end-state" of conceptual development in older and presumably more advanced individuals such as undergraduate students has received much less attention (Coley, 2000). We identified instances of construal-based reasoning in participants' explanations for their agreement or disagreement with the misconception statements based on consensus among multiple, independent, trained coders. Results show that a majority of students explicitly used each type of construal (teleological, essentialist, and anthropocentric thinking) in their written explanations on at least one occasion. Although the mean frequencies for each construal may appear low (see Figure 7), our coding system likely underestimates the use of intuitive construal-based reasoning among college students, for at least two reasons. First, such construals are typically implicit, and our coding system captured only explicit construal-based reasoning (see Taber and Garcia-Franco, 2010, for a discussion of the role of implicit knowledge in students' scientific explanation). Second, we utilized a relatively conservative criterion (4/6 independent coders) for identifying instances of each construal. Thus, we conclude that intuitive construal-based reasoning is readily observable among entering university students.

Indeed, we observed few differences in construal-based reasoning between biology majors and nonmajors, documenting that intuitive construal-based reasoning is readily observable in the written responses of both of these populations. This fits with other recent work showing evidence of intuitive biases in adult reasoning (e.g., Shtulman and Valcarcel, 2012; Kelemen et al., 2013; Eidson and Coley, 2014). It also fits with previous demonstrations of students' spontaneous and explicit use of intuitive cognitive construals in discipline-based biology education research literature (e.g., Tamir and Zohar, 1991; Friedler, et al., 1993; Zohar and Ginossar, 1998; Nehm and Ridgeway, 2011). For the fields of cognitive and developmental psychology, which have focused largely on such reasoning among elementary school 
children, these findings clearly demonstrate the persistence of construal-based intuitive biological reasoning into young adulthood.

Even more striking was the lack of differences between biology majors and nonmajors in their use of construal-based reasoning in discipline-based biology problems. Indeed, differences in misconceptions, albeit small, were systematic, whereas differences in construal-based reasoning were virtually nonexistent in these investigations. Although the biology majors were all first-semester undergraduates, and therefore at the very beginning of a university-level life sciences curriculum, they had successfully navigated a high school-level science curriculum rigorous enough to enable them to score well on the standardized AP test. These results may seem counterintuitive, because one might hypothesize that greater experience in formal education in biology might have caused biology majors to abandon intuitive ways of reasoning, especially about explicitly biological content. Our results suggest otherwise.

\section{How Are Construal-Based Reasoning and Misconceptions Related, and Are Those Relations the Same for Biology Majors and Nonmajors?}

Our most critical hypotheses were that the presence of construal-based reasoning would be positively associated with the strength and prevalence of misconceptions and that such associations would be exclusive and construal specific. For example, we hypothesized that the presence of teleological construal-based reasoning would be associated with agreement with hypothesized teleological misconceptions but not necessarily with hypothesized essentialist or hypothesized anthropocentric misconceptions. Our results support these predictions. For three of four teleological misconception statements, agreement with the misconception was associated with students' use of explicit teleological reasoning in their written explanations. Likewise, for all four of the essentialist misconception statements, agreement with the misconception was associated with students' use of explicit essentialist reasoning in their written explanations. These results are consistent with previous work showing that misconceptions about evolution are associated with essentialist thinking (e.g., Shtulman and Schulz, 2008) and teleological thinking (e.g., Kelemen and Rossett, 2009). They also extend these findings by demonstrating a linkage between systems of misconceptions that transcend traditional biological subject areas and underlying intuitive cognitive construals. This pattern of results in turn supports our primary hypothesis.

When results were aggregated across responses to all items, we observed a striking difference in the relations between construal-based reasoning and misconception agreement for biology majors compared with nonmajors. Specifically, for biology majors, we saw very specific and precise relations; the frequency of teleological construals in written explanations was associated exclusively with agreement with teleological misconception statements, and frequency of essentialist construals in written explanations was associated exclusively with agreement with essentialist misconception statements. In contrast, for nonmajors, the overall frequency of construals in written explanations was unrelated to their agreement with corresponding misconception statements.
This raises the intriguing possibility that formal education in the biological sciences might actually serve to reify intuitive biological thought among biology majors, resulting in stronger and more specific relations between construal-based reasoning and agreement with related misconceptions than for nonmajors. As a reminder to the reader, biology majors were those students who had scored a 4 or 5 on the AP Biology exam in high school, as compared with nonmajors who had not, but who had achieved similarly on a non-biology AP exam. Unfortunately, no additional information is available about the high school biology experiences of students in this study. In future studies, collection of more detailed information on subjects' high school biology instruction could inform the interpretation of results.

Interestingly, for hypothesized anthropocentric misconception statements, the relation between construal-based reasoning and misconception agreement was weaker. Agreement was associated with used of explicit anthropocentric reasoning on only one out of four misconception statements, and regression analysis revealed no relation between agreement and use of anthropocentric reasoning across all explanations. However, this does not appear to be due to a lack of agreement with the misconceptions hypothesized to be based in anthropocentric thinking nor due to a lack of instances of anthropocentric reasoning in students' written statements. Rather, we simply observed much weaker interrelations between construal-based reasoning and misconception agreement for anthropocentric thinking than we did for teleological thinking or essentialist thinking. There are several possible explanations for this finding. Interactions between anthropocentric thinking and biological misconceptions might be fundamentally different from those for essentialist thinking and teleological thinking. Alternatively, if the origin of these relations is in formal biology education, perhaps anthropocentric reasoning is less often used in making complex biological ideas accessible to novices and therefore less strongly linked to misconceptions. Perhaps our anthropocentric challenge statements were nonrepresentative; Talanquer $(2010,2013)$, for instance, finds teleological thinking on a very specific subset of chemistry problems (i.e., those having to do with osmotic flow but not with freezing and boiling points of solutions). Or perhaps our coding system was insufficiently sensitive to anthropocentric thinking. Further research will be needed to sort out these possibilities.

\section{Future Research Directions: Origins, Persistence, and Generality}

The findings presented above represent an initial foray into exploring the interactions between intuitive ways of knowing from psychology and misconceptions observed in formal biology education. In line with our hypotheses, we have demonstrated specific linkages between construal-based intuitive reasoning and particular sets of biological misconceptions. We have also shown that relations between intuitive reasoning and misconceptions differ for biology majors versus nonmajors. These findings raise questions about the origins, persistence, and generality of relations between intuitive reasoning and biological misconceptions. We explore below three lines of potential future research directions.

With respect to the origins, our evidence suggests that relations between construal-based reasoning and biological 
misconceptions are stronger and more specific among biology majors than nonmajors. This difference raises the question of why those students with presumably more disciplinary interest in biology and perhaps more formal education in biology would be more likely to employ specific construal-based reasoning (e.g., essentialist reasoning) in their biological explanations of specific misconceptions (e.g., hypothesized essentialist misconceptions). One hypothesis is that formal secondary biology education itself may be somehow either driving or reifying these relations. If this were the case, one might hypothesize that construal-based reasoning would be found in the language of instruction among high school biology teachers. While it would be unexpected for high school biology teachers to exhibit the same relations as the entering biology majors studied here, these same individuals may unknowingly employ teleological and essentialist reasoning in their attempts to make complex biological ideas accessible to high school students. Multiple lines of previous research have investigated the extent to which teachers themselves may embrace common biological misconceptions (e.g., Nehm and Schonfeld, 2007). Additionally, Sadler and colleagues (2013) have documented that those teachers who are best able to predict students' misconceptions and inaccurate reasoning are those teachers who are able to promote the largest learning gains for students. An investigation of how high school biology teachers perform on the assessments used here could clarify whether they also exhibit specific relations between construal-based reasoning and misconception agreement. Additionally, analysis of transcripts of the language used to teach those ideas related to the most agreed-with teleological (e.g., "Many species develop protective camouflage to avoid predators") and essentialist misconceptions (e.g., "Apart from differences due to age and sex, members of the same species are essentially identical") might reveal the use of construal-based language in biology teaching by high school instructors, even if they themselves do not endorse these relationships when assessed.

With respect to persistence, one wonders how formal undergraduate biology education will affect these specific relations between misconception agreement and construal-based reasoning. The findings presented here were only for those students who were beginning their university studies. If formal university biology education somehow disavows biology majors of biological misconceptions and the use of construal-based reasoning in biology, then we would hypothesize that, in a cross-sectional study, advanced or graduating biology majors would neither agree with the biological misconception statements used here nor employ construal-based reasoning in their explanations. Alternatively, if formal biology education is either not affecting or even driving these relations, we might hypothesize that biological misconception statements would persist among advanced or graduating biology majors and that the relations between their misconception agreement and construal-based reasoning might even increase in specificity (e.g., use of teleological reasoning in explaining hypothesized teleological misconception statements). Further, the persistence of these relations among advanced biology majors would make inquiry into the language used in college biology classrooms ripe for study. Similar to the high school biology teaching investigations proposed earlier, it would be unexpected for university biology instructors to exhibit the same relations as entering biology majors; however, they may unknowingly employ construal-based reasoning in the language of their teaching.

Finally, further research is needed to explore how extensive the relations between misconception agreement and construal-based reasoning really are with respect to a large set of misconception statements related to the three cognitive construals under study, and perhaps other cognitive construals as well. While these patterns were for the most part consistent for the misconception statements we examined, there may be other biological misconception statements that are rooted in multiple cognitive construals and that may therefore be simultaneously associated with several types of construal-based reasoning. To assess these and other possibilities, investigation of a larger set of randomly chosen misconceptions is important to extend the present findings and examine how robust these specific relations between misconceptions and construal-based reasoning are for biology majors.

\section{CONCLUSIONS}

In conclusion, the findings presented here represent a fruitful initial investigation of the interactions between intuitive ways of knowing long studied in cognitive psychology and misconceptions previously documented through biology education research. We found that the vast majority of university undergraduates in this study exhibited agreement with one or more biological misconception statements, with nonmajors being slightly more likely to agree than biology majors. In addition, both biology majors and nonmajors commonly used explicit teleological, essentialist, and anthropocentric reasoning in their explanations of misconception statements, with few differences observed between the two populations. Finally, and most importantly, our findings show very specific patterns of association between construal-based reasoning and biological misconceptions; moreover, these relations were stronger and more specific among biology majors than nonmajors. Taken together, these results complement previous findings in cognitive science and biology education research. They also extend these findings by demonstrating a linkage between systems of misconceptions that transcend traditional biological subject areas and underlying intuitive cognitive construals. They support the hypothesis that at least some common biological misconceptions may stem not from the complexity or opacity of the concepts themselves but from informal, intuitive ways of understanding the world (Coley and Tanner, 2012). They also raise the alarming possibility that formal education in the biological sciences might actually serve to reify intuitive biological thought, resulting in stronger and more specific relations between construal-based reasoning and agreement with related misconceptions. Finally, these findings suggest that further systematic investigation of issues at the interface of cognitive psychology and biology education, more generally, are ripe for investigation.

\section{ACKNOWLEDGMENTS}

This research was supported by National Science Foundation CAREER Award \#0954127 to K.D.T. and by a Northeastern University College of Science Seed Grant to J.D.C. We thank Melanie Arenson, 
Jessalyn Kelleher, and other members of the Categorization and Reasoning Lab in the Department of Psychology at Northeastern University for their outstanding work on data collection and coding. We are also indebted to members of the CRL at Northeastern and to members of SEPAL: Science Education Partnership and Assessment Laboratory in the Department of Biology at San Francisco State University for helpful comments and discussion.

\section{REFERENCES}

Ahn W, Kalish C, Gelman SA, Medin DL, Luhmann C, Atran S, Coley JD, Shafto P (2001). Why essences are essential in the psychology of concepts. Cognition 82, 59-69.

American Association for the Advancement of Science (AAAS) (2011). Vision and Change in Undergraduate Biology Education: A Call to Action, Washington, DC.

AAAS (2014a). Project 2061: Evolution and Natural Selection. http:/ / assessment.aaas.org/topics/EN\#/,tabs-265/2,tabs-264/2,tabs-262/2 (accessed 20 May 2014).

AAAS (2014b). Project 2061: Interdependence in Ecosystems. http:/ / assessment.aaas.org/topics/IE\#/,tabs-173/2,tabs-176/2 (accessed 20 May 2014).

Anderson CW, Sheldon TH, DuBay J (1990). The effects of instruction on college nonmajors' conceptions of respiration and photosynthesis. J Res Sci Teach 27, 761-776.

Anderson DL, Fisher KM, Norman GJ (2002). Development and evaluation of the Conceptual Inventory of Natural Selection. J Res Sci Teach 39, 952-978.

Arnaudin MW, Mintzes JJ (1985). Students' alternative conceptions of the human circulatory system: a cross-age study. Sci Educ 69, 721-733.

Atran S, Medin DL (2008). The Native Mind and the Cultural Construction of Nature, Boston, MA: MIT Press.

Berlin B (1992). Ethnobiological Classification: Principles of Categorization of Plants and Animals in Traditional Societies, Princeton, NJ: Princeton University Press.

Bishop BA, Anderson CW (1990). Student conceptions of natural selection and its role in evolution. J Res Sci Teach 27, 415-427.

Braaten M, Windschitl M (2011). Working toward a stronger conceptualization of scientific explanation for science education. Sci Educ 95, 639-669.

Carey S (1985). Conceptual Change in Childhood, Cambridge, MA: MIT Press.

Coley JD (2000). On the importance of comparative research: the case of folkbiology. Child Dev 71, 82-90.

Coley JD (2007). The human animal: developmental changes in judgments of taxonomic and psychological similarity among humans and other animals. Cogn Brain Behav 11, 733-756.

Coley JD, Muratore TM (2012). Trees, fish, and other fictions: folk biological thought and its implications for understanding evolutionary biology. In: Evolution Challenges: Integrating Research and Practice in Teaching and Learning about Evolution, ed. KS Rosengren, S Brem, EM Evans, and G Sinatra, New York: Oxford University Press, $22-46$.

Coley JD, Solomon GEA, Shafto P (2002). The development of folkbiology: a cognitive science perspective on children's understanding of the biological world. In: Children and Nature: Psychological, Sociocultural and Evolutionary Investigations, ed. P Kahn and S Kellert, Cambridge, MA: MIT Press, 65-91.

Coley JD, Tanner KD (2012). Common origins of diverse misconceptions: cognitive principles and the development of biological thinking. CBE Life Sci Educ 11, 1-7.

D'Avanzo C (2003). Application of research on learning to college teaching: ecological examples. BioScience 53, 1121-1128.
diSessa A (1988) Knowledge in pieces. In: Constructivism in the Computer Age, ed. G Forman and PB Pufall, Hillsdale, NJ: Lawrence Erlbaum, 49-70.

diSessa A (1993). Toward an epistemology of physics. Cogn Instr 10, 105-225.

Eidson RC, Coley JD (2014). Not so fast: gender essentialism in young adults. J Cogn Dev 15, 382-292.

Evans EM (2008).Conceptual change and evolutionary biology: a developmental analysis. In: International Handbook of Research on Conceptual Change, ed. S Vosniadou, New York: Routledge, 263294.

Evans EM, Rosengren K, Lane JD, Price KS (2012). Encountering counterintuitive ideas: constructing a developmental learning progression for biological evolution. In: Evolution Challenges: Integrating Research and Practice in Teaching and Learning about Evolution, ed. KS Rosengren, S Brem, EM Evans, and G Sinatra, New York: Oxford University Press, 174-199.

Friedler Y, Zohar A, Tamir P (1993). The effect of age and of learning on the ability to distinguish between anthropomorphic and teleological explanations. Int J Sci Educ 15, 439-443.

Gelman SA (2003). The Essential Child: Origins of Essentialism in Everyday Thought, New York: Oxford University Press.

Gelman SA, Rhodes M (2012). "Two-thousand years of stasis": how psychological essentialism impedes evolutionary understanding. In: Evolution Challenges: Integrating Research and Practice in Teaching and Learning about Evolution, ed. KS Rosengren, S Brem, EM Evans, and G Sinatra, New York: Oxford University Press, 3-21.

Gelman SA, Wellman HM (1991). Insides and essences: early understandings of the non-obvious. Cognition 38, 213-244.

Gentner D, Smith LA (2013). Analogical learning and reasoning. In: The Oxford Handbook of Cognitive Psychology, ed. D Reisberg, New York: Oxford University Press, 668-681.

Gopnik A (2000). Explanation as orgasm and the drive for causal understanding: the evolution, function and phenomenology of the theory-formation system. In: Cognition and Explanation, ed. F Keil and R Wilson, Cambridge, MA: MIT Press, 299-323.

Greene E (1990). The logic of university students' misunderstanding of natural selection. J Res Sci Teach 27, 875-885.

Grotzer TA (2003). Learning to understand the forms of causality implicit in scientifically accepted explanations. Stud Sci Educ 39, 11-74.

Gunckel KL, Covitt BA, Salinas I, Anderson CW (2012). A learning progression for water in socio-ecological systems. J Res Sci Teach $49,843-868$.

Hackling MW, Treagust D (1984). Research data necessary for meaningful review of grade ten high school genetics curricula. J Res Sci Teach 21, 197-209.

Hartley LM, Wilke BJ, Schramm JW, D'Avanzo C, Anderson CW (2011). College students' understanding of the carbon cycle: contrasting principle-based and informal reasoning. BioScience 61, 65-75.

Hull DL (1965). The effect of essentialism on taxonomy: two thousand years of stasis. Br J Philos Sci 15, 314-326.

Inagaki K, Hatano G (1991). Constrained person analogy in young children's biological inference. Cogn Dev 6, 219-231.

Inagaki K, Hatano G (2002). Young Children's Naive Thinking about the Biological World, New York: Psychology Press.

Inagaki K, Hatano G (2006). Young children's conception of the biological world. Curr Dir Psychol Sci 15, 4177-181.

Kahneman D (2012). Thinking Fast and Slow, New York: Farrar, Straus and Giroux.

Keil FC (1989). Concepts, Kinds, and Cognitive Development, Cambridge, MA: MIT Press. 
Keil FC (2006). Explanations and understanding. Annu Rev Psychol $57,227-254$

Kelemen D (1999). The scope of teleological thinking in preschool children. Cognition 70, 241-272.

Kelemen D (2012). Teleological minds: how natural intuitions about agency and purpose influence learning about evolution. In: Evolution Challenges: Integrating Research and Practice in Teaching and Learning about Evolution, ed. KS Rosengren, SK Brem, EM Evans, and GM Sinatra, New York: Oxford University Press.

Kelemen D, Rossett E (2009). The human function compunction: teleological explanation in adults. Cognition 111, 138-143.

Kelemen D, Rottman J, Seston R (2013). Professional physical scientists display tenacious teleological tendencies. Purpose-based reasoning as a cognitive default. J Exp Psychol: General 142, 1074-1083.

Knight JK, Wood WB (2005). Teaching more by lecturing less. Cell Biol 4, 298-310.

Köse S (2008). Diagnosing student misconceptions: using drawings as a research method. World Appl Sci J 3, 283-293.

Kuech R, Zogg G, Zeeman S, Johnson M (2003). Technology rich biology labs: effects of misconceptions. Paper presented at the National Association from Research in Science Teaching (NARST) Annual Conference, held 22-26 March 2003 in Philadelphia, PA.

Leach J, Driver R, Scott P, Wood-Robinson C (1992). Progression in Understanding of Ecology Concepts by Pupils Aged 5 to 16, Leeds, UK: Children's Learning in Science Research Group, Centre for Studies in Science and Mathematics Education, University of Leeds.

Legare CH, Lane J, Evans EM (2013). Anthropomorphizing science: how does it affect the development of evolutionary concepts? Merrill-Palmer Q 59, 168-197.

Leonard MJ, Kalinowski ST, Andrews TC (2014). Misconceptions yesterday, today and tomorrow. CBE Life Sci Educ 13, 179-186.

Marbach-Ad G, Briken V, El-Sayed NM, Frauwirth K, Fredericksen B, Hutcheson S, Gao L-Y, Joseph SW, Lee V, McIver KS, et al. (2009). Assessing student understanding of host pathogen interactions using a concept inventory. J Microbiol Educ 10, 43-50.

Maskiewicz AC, Lineback JE (2013). Misconceptions are "so yesterday!" CBE Life Sci Educ 12, 352-356.

Mayr E (1982). The Growth of Biological Thought: Diversity, Evolution and Inheritance, London: Belknap.

Medin DL, Ortony A (1989). Psychological essentialism. In: Similarity and Analogical Reasoning, ed. S Vosniadou and A Ortony, Cambridge, New York Cambridge University Press, 179-195.

Miller JL, Bartsch K (1997). The development of biological explanation: are children vitalists? Dev Psychol 33, 156-164.

Mohan L, Chen J, Anderson CW (2009). Developing a multi-year learning progression for carbon cycling in socio-ecological systems. J Res Sci Teach 46, 675-698.

Morris SC, Taplin JE, Gelman SA (2000). Vitalism in naive biological thinking. Dev Psychol 36, 582-595.

Murphy GL (2002). The Big Book of Concepts, Cambridge, MA: MIT Press.

Nehm RH, Ridgway J (2011). What do experts and novices "see" in evolutionary problems? Evo Educ Outreach 4, 666-679.

Nehm RH, Schonfeld IS (2007). Does increasing biology teacher knowledge of evolution and the nature of science lead to greater preference for the teaching of evolution in schools? J Sci Teach Educ 18, 699-723.

Özay E, Oztas H (2003). Secondary students' interpretations of photosynthesis and plant nutrition. J Biol Educ 37, 68-70.
Passmore C, Stewart J (2002). A modeling approach to teaching evolutionary biology in high schools. J Res Sci Teach 39, 185-204.

Posner GJ, Strike KA, Hewson PW, Gertzog WA (1982). Accommodation of a scientific conception: towards a theory of conceptual change. Sci Educ 66, 211-227.

Rips LJ (1989). Similarity, typicality, and categorization. In: Similarity and Analogical Reasoning, ed. S Vosniadou and A Ortony, Cambridge, New York: Cambridge University Press, 21-59.

Sadler P, Sonnert G, Coyle H, Cook-Smith N, Miller J (2013). The influence of teachers' knowledge on student learning in middle school physical science classrooms. Am Educ Res J 50, 1020-1049.

Shi J, Martin JM, Guild NA, Vincens Q, Knight JK (2010). A diagnostic assessment for introductory molecular and cell biology. CBE Life Sci Educ 9, 453-461.

Shtulman A (2006). Qualitative differences between naïve and scientific theories of evolution. Cogn Psychol 52, 170-194.

Shtulman A, Calabi P (2012). Cognitive constraints on the understanding and acceptance of evolution. In: Evolution Challenges: Integrating Research and Practice in Teaching and Learning about Evolution, ed. KS Rosengren, S Brem, EM Evans, and G Sinatra, New York: Oxford University Press, 47-65.

Shtulman A, Schulz L (2008). The relation between essentialist beliefs and evolutionary reasoning. Cogn Sci 32, 1049-1062.

Shtulman A, Valcarcel J (2012). Scientific knowledge suppresses but does not supplant earlier intuitions. Cognition 124, 209-215.

Sloman SA (2005). Causal Models: How We Think about the World and Its Alternatives, New York: Oxford University Press.

Smith MK, Wood WB, Knight JK (2008). The Genetics Concept Assessment: a new concept inventory for gauging student understanding of genetics. CBE Life Sci Educ 7, 422-430.

Solomon G, Johnson SC, Zaitchik D, Carey S (1996). Like father like son: young children's understanding of how and why offspring resemble their parents. Child Dev 67, 151-171.

Songer CJ, Mintzes JJ (1994). Understanding cellular respiration: an analysis of conceptual change in college biology. J Res Sci Teach 31, 621-637.

Stavy R, Eisen Y, Yaakobi D (1987). How students aged 13-15 understand photosynthesis. Int J Sci Educ 9, 105-115.

Stern L, Roseman JE (2004). Can middle-school science textbooks help students learn important ideas? Findings from Project 2061's curriculum evaluation study: Life Science. J Res Sci Teach 41, $538-568$

Taber KS, Garcia-Franco A (2010). Learning processes in chemistry: drawing upon cognitive resources to learn about particulate structure of matter. J Learn Sci 19, 99-142.

Talanquer V (2006). Commonsense chemistry: a model for understanding students' alternative conceptions. J Chem Educ 83, 811816.

Talanquer V (2007). Explanations and teleology in chemistry education. Int J Sci Educ 29, 853-870.

Talanquer V (2010). Exploring dominant types of explanations built by general chemistry students. Int J Sci Educ 32, 2393-2412.

Talanquer V (2013). When atoms want. J Chem Educ 90, 14191424.

Tamir P (1989). Some issues related to the use of justifications to multiple-choice answers. J Biol Educ 23, 285-292.

Tamir P, Zohar A (1991). Anthropomorphism and teleology in reasoning about biological phenomena. Sci Educ 75, 57-67.

Vosniadou S (1994). Capturing and modeling the process of conceptual change. Learn Instr 4, 45-69. 
Vosniadou S (2002). On the nature of naïve physics. In: Reconsidering Conceptual Change: Issues in Theory and Practice, ed. M Limón and L Mason, Dordrecht, The Netherlands: Kluwer Academic, 61-76.

Wandersee JH (1986). Can the history of science help science educators anticipate students' misconceptions? J Res Sci Teach 23, 581-597.

Wandersee JH, Mintzes JJ, Novak JD (1994). Research on alternative conceptions in science. In: Handbook of Research on Science
Teaching and Learning, ed. D Gabel, New York: Macmillan, 177-210.

Westbrook S, Marek E (1992). A cross-age study of student understanding of the concept of homeostasis. J Res Sci Teach 29, 51-61.

Zohar A, Ginossar S (1998). Lifting the taboo regarding teleology and anthropomorphism in biology education-heretical suggestions. Sci Educ 82, 679-697. 